\title{
Feasibility Study of Concrete Louvers for High-rise Residential Buildings in Terms of Cooling Energy Requirements
}

\author{
Sara Dh. Bahaadin ${ }^{1}$, Binaee Y. Raof ${ }^{1}$ and Hendren H. Abdulrahman ${ }^{2}$ \\ ${ }^{1}$ Department of City Planning, Technical College of Engineering, Sulaimani Polytechnic University, \\ Sulaimani, Kurdistan Region - F.R. Iraq \\ ${ }^{2}$ Department of Architecture, College of Engineering, University of Sulaimani, \\ Sulaimani, Kurdistan Region - F.R. Iraq
}

\begin{abstract}
High-rise residential buildings are increasing worldwide, including cities in the Kurdistan Region of Iraq. Therefore, creating sustainable environments in and around these residential buildings are becoming an important problem. Improving energy efficiency in buildings has received critical attention worldwide. Countries have developed national sustainability strategies that lead to the lower energy consumption while maintaining comfort, reducing energy consumption, and minimizing harmful emissions. In this paper, an analysis of the impact of external shading devices in high-rise residential buildings on energy consumption of a 13-storey building in Sulaimani city is studied. The study is focused on fixed shading elements, explaining the influence of the design of vertical and horizontal shading devices on the total energy consumption of this type of building. The results show that both a single fixed horizontal blind with a depth of $20 \mathrm{~cm}$ and a triple vertical shading with the same depth are considered useless. The reduction in cooling loads by two fixed horizontal louvers almost doubled compared to a single fixed horizontal shading with $20 \mathrm{~cm}$. Moreover, triple fixed horizontal louvers with $40 \mathrm{~cm}$ have almost the same effect on reducing cooling loads as triple fixed louvers with $60 \mathrm{~cm}$. On the other hand, a triple fixed horizontal shading device with $60 \mathrm{~cm}$ has twice the effect on reducing annual cooling loads as a triple fixed vertical shading device with $60 \mathrm{~cm}$.
\end{abstract}

Index Terms-High-rise building; Shading devices; cooling loads; Energy consumption; Sulaimani city.

\section{INTRODUCTION}

Since scientific research on the subject of housing has shown that the experience of living in high-rise apartments varies greatly for different people, cultures, and environmental conditions. For example, a European's perception of living

ARO-The Scientific Journal of Koya University Vol. VIII, No.2 (2020), Article ID: ARO.10743, 12 pages DOI:10.14500/aro.10743

Received: 26 October 2020; Accepted: 14 February 2021



Regular research paper: Published: 01 March 2021

Corresponding author's e-mail: sara.bahaadin@spu.edu.iq

Copyright (C) 2021 Sara Dh. Bahaadin, Binaee Y. Raof and

Hendren H. Abdulrahman. This is an open-access article distributed under the Creative Commons Attribution License. in a high-rise is not desirable, whereas in many Asian cities, people prepared to live in high-rise blocks (Arsalan and Sev, 2014).

Some observers believe that high-rise residential buildings, especially sustainable housing, are a fundamental commitment to urban life that should be maintained and improved.

Tall buildings have many environmental benefits, for example, sufficient access to sunlight to install solar panels. On the other hand, a high-rise residential building requires a large amount of energy for its operation and utilities. Many high-rise buildings consume more energy per inhabitant than a well-built townhouse and not much less than a small, wellbuilt detached house (Ali and Al-Kodmany, 2012).

Today, almost all countries have national sustainability strategies in place and energy efficiency is undeniably one of the main pillars of sustainability. Therefore, environmental impact assessment is a key priority when designing new high-rise residential projects (Ali and Al-Kodmany, 2012).

In most countries, buildings require large amounts of energy for both cooling and heating. Furthermore, in the last decade in the Kurdistan region about $50 \%$ of the total energy consumption was consumed in the residential sector (Morad and Ismail , 2017). Indeed, cooling loads due to solar gains represent about half of the global cooling loads for residential and non-residential buildings (Datta, 2001).

To control the effect of solar energy on the indoor climate, one usually focuses on the role of the building skin and fenestration, which act as filters between outside and inside of the building. Heat transfer can take place through radiation, ventilation, conduction, and convection. Here, the focus is on windows, which is the critical point for indoor heat gains. Glazing can account for up to $22 \%$ of energy consumption in residential buildings. Uncontrolled heat gain through windows leads to overheating and, thus, to poor thermal performance (Tariq and Jinia, 2012). The solar radiation that passes through windows has two effects on the thermal environment indoors: (1) Direct effects due to the incidence of direct and diffuse solar radiation on people, and (2) indirect effects due to the absorption of part of the 
solar radiation by the interior surfaces of the room and the furnishings (Athienitis and Haghighat, 1992). Furthermore, the most excellent source of heat gain may be solar radiation entering through an opening (Tariq and Jinia, 2012). To reduce heat gain, the surfaces on which the sun rays fall must be protected, with emphasis on shading devices, since windows allow most of the incident heat to penetrate, thereby increasing the risk of overheating (Datta, 2001).

External shading devices on a building façade considered a passive design strategy as they reduce solar radiation, which is the most important factor affecting the architectural environment. Many studies have demonstrated the benefits of external shading devices, but some of them are designed for esthetic purposes only, without taking account of their high potential for reducing solar radiation (Shahdan, et al., 2018).

External shading devices are used to block solar radiation before reaching inside the building. They are therefore more effective than internal shading devices and offer better performance in terms of shading and visibility. A series of simulations and measurements have verified the differentiated advantages in illumination and building energy consumption using this system (Kim and Kim, 2010). However, other parameters can be influenced by external shading devices, such as daylight and natural ventilation performance of the building. Consequently, the design and construction of external shading devices must be carefully studied and correctly designed to ensure effective functioning (Tariq and Jinia, 2012).

\section{Previous Studies}

A wide number of parametric studies on sun oriented shading devices and energy uses have been made since the improvement of energy simulation computer programs.

The available literature examines what savings can be achieved by using external shading units. Different methods have been examined; the most common method is energy simulation software to determine energy savings using the external shading units.

In 2017, Idchabani, et al., 2017, investigated the influence of external shading overhangs and devices on the energy performance of buildings in a hot climate. Depending on the orientation of the window and the dimensions of the overhangs and slats in the city of Marrakech, different situations were simulated. In the analysis, it was criticized that the devices have less influence on the reduction of the cooling demand than the overhangs, and the most significant reduction was found for the directions NE and the NW area. However, the strongest reduction of the cooling load in SE and SW orientations was found for the overhang projection.

A study by Datta, 2001 examined the effect of fixed horizontal devices and their impact on the thermal performance of buildings using TRNSYS simulation. The shading devices were optimized in terms of annual energy loads and the optimal plan was designed according to the area's climate. It was found that the shading factor varies according to the time of day and is different for summer and winter (Datta, 2001).
Besides, as highlighted in the work of Alzoubi and AlZoubi, 2010 each side of a building requires a different shading treatment, as sunlight is incident from different angles on each side. Besides, there is an optimal orientation for shading devices that keep the internal light level within the acceptable range with a minimum amount of solar gain.

The study by Abdel Monteleb and Ali highlighted the effect of horizontal shading overhangs on the thermal performance of indoor spaces in residential buildings in New Assiut city, which has a hot, arid desert climate. The study shows that $100 \mathrm{~cm}$ wide horizontal overhangs had the lowest ambient temperature values for all tested orientations, with a strong recommendation to increase the use of overhangs in the south facade. In contrast, $12 \mathrm{~cm}$ horizontal overhangs had the highest ambient temperature values for all selected orientations. The wider the overhang, the lower the ambient temperature. Furthermore, the increase in the overhang width from $12 \mathrm{~cm}$ to $100 \mathrm{~cm}$ resulted in a decrease in room temperature by $2^{\circ} \mathrm{C}$. This reduction in temperature applies to the east, west, and south façades, whereas it is insignificant for the north façade (AbdelMonteleb, 2013)

However, in another article by Abd El-Monteleb and Ali, the influence of vertical shading devices on the thermal performance of residential buildings for the same city (New Assiut) was clarified, the results showed that the $38 \mathrm{~cm}$ wide vertical slats lead to a reduction of the indoor temperature around $2{ }^{\circ} \mathrm{C}$ in all the same three orientations as mentioned for horizontal shadow overhangs. However, for the northern façade, the result is similar to the research paper mentioned above (Abd El-Monteleb and Ahmed, 2012).

There is a lack of research to investigate the effects of fixed shading devices on cooling energy demand. In the meantime, study gap is there is no specific study on the impact of the width and number of fixed horizontal and vertical shading devices on the cooling loads for high-rise residential buildings with different orientations.

Therefore, this research attempts to answer the following question: To what extent the parametric variables (width, number, and orientation) of fixed horizontal and vertical shading elements are related to the annual cooling loads of residential high-rise buildings in the city of Sulaimani or another location with similar climatic characteristics.

There is a lack of research on the effects of fixed shading devices on energy demand for Sulaimani climate and condition. Meanwhile, there is no specific study on the impact of the width and number of fixed horizontal and vertical shading devices on the cooling loads for high-rise residential buildings with different orientations.

\section{AIMS of The STUdY}

The focus of this study is to review and to assess the impact of different orientations on the actual cooling energy consumption of a typical high-rise residential building. It is an investigation of the correlation between the reduction of cooling loads in these buildings and the construction and the design of fixed shading devices in various forms such as 
vertical and horizontal. Furthermore, the setting of parameters for the required width and number of both vertical and horizontal fixed shading devices for frequently used opening sizes in typical high-rise residential buildings.

The research tries to find a suitable selection of shading elements that have a significant influence on the energy performance of such residential buildings.

\section{METHODOLOGY}

To fill the knowledge gap identified above, a study will be conducted for a high-rise residential building in the city of Sulaimani through a computer simulation analysis using the DesignBuilder software(DesignBuilder, 2018) to determine the potential for annual savings of cooling energy through the use of fixed shading devices. Design Builder is exclusive software designed to model and to evaluate the environmental design and performance of buildings. This program uses climate data provided by the EnergyPlus simulation engine to calculate the energy consumption of buildings in terms of cooling, heating, and lighting loads (Shaeri, et al., 2019). It has been used consistently in many studies in this field. Furthermore, the reason for choosing this tool and method is the time and energy savings achieved by modeling the case in computer software instead of creating an actual model for testing and evaluation.

The study focuses on comparing and evaluating the effects of using different shading devices, namely, fixed horizontal and vertical shading elements, on all different window orientations in terms of annual cooling load requirements and total energy consumption. The main factors in this study are solar heat gain and direct normal solar radiation, as they have a direct influence on indoor air temperature and consequently on cooling loads.

The simulation process will be based on two main scenarios. A comparison will be made between these scenarios in terms of the effect of each type of proposed shading element on the changes they have on the annual and monthly cooling loads.

\section{Sulaimani Climate}

The city of Sulaimani is located in Kurdistan Region in Iraq, at a latitude of $35^{\circ} 33^{\prime} 53.86^{\prime \prime} \mathrm{N}$ and a longitude of $45^{\circ} 25^{\prime} 58.44^{\prime \prime} \mathrm{E}$ (Date and Time .Info, 2020). And according to Koeppen's world map, it has a Mediterranean climate with dry summers and cool, wet winters (Csa) zone (Kottek , et al., 2006)

The climatic characteristics of Sulaimani are cold and rainy in winter, mild in spring and autumn. The city is characterized by long hot summer with high solar radiation, low humidity, and moderate rainfall. Fig. 1 shows the yearround temperatures for Sulaimani. The figure shows that the maximum temperature in January is $13^{\circ} \mathrm{C}$, and the minimum is almost $-14^{\circ} \mathrm{C}$. Furthermore, the maximum temperature in July is $42^{\circ} \mathrm{C}$.

In Sulaimani, direct solar radiation reaches its minimum in December and February, which is about $400 \mathrm{Wh} / \mathrm{m}^{2}$, while the maximum radiation reaches almost $700 \mathrm{Wh} / \mathrm{m} 2$ in August, as shown in Fig. 2.

\section{The Case Study}

One of the 23 high-rise residential buildings located at Darwaza city residential complex at the southern part of Sulaimani city in Kurdistan region of Iraq has been selected as the high-rise case study residential building because it has 13 floor and the building facades have windows in all orientations with no shading elements. The building is a point block (Neufert, et al., 2000) with a square-shaped layout. The total building gross floor area is $7696 \mathrm{~m}^{2}$. The reason for choosing this building is that it is the most popular design type for high-rise residential buildings in Sulaimani and has the general configurations of this building type and also

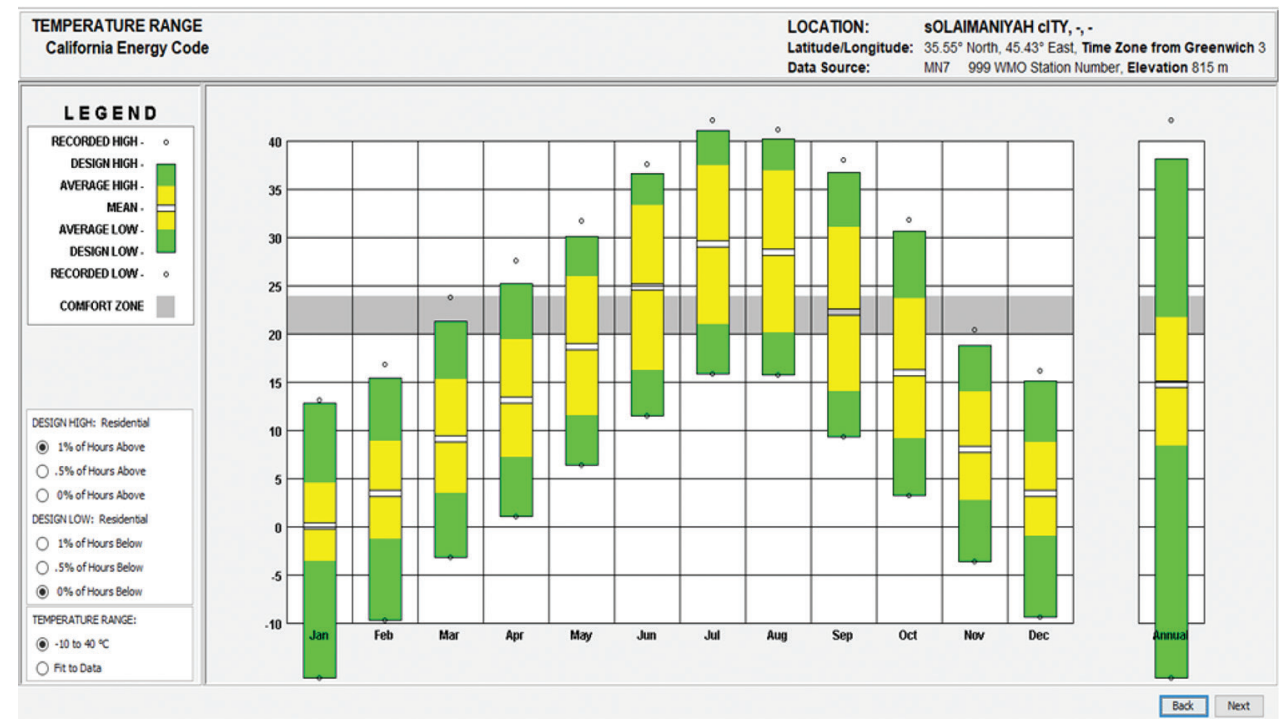

Fig. 1. Sulaimani air temperature data, based on the Sulaimani weather data file. Reproduced by climate consultant $6.0 \mathrm{software}, 400 \mathrm{Wh} / \mathrm{m}^{2}$, whereas the maximum radiation reaches almost $700 \mathrm{Wh} / \mathrm{m}^{2}$ in August, see Fig. 2. 
because it consumes a large amount of energy for cooling, which is about $377,000 \mathrm{kWh}$ annually, Figs. 3 and 4.

The building is detached therefore it is facing all the four orientations (north, east, south, and west), However, on each floor, each apartment has two orientations, as shown in Table I. There are four apartments and a staircase on each floor, the total floor area is $592.6 \mathrm{~m}^{2}$, the area of each apartment is approximately $148.2 \mathrm{~m}^{2}$, with a ceiling height of $2.60 \mathrm{~m}$. Furthermore, each apartment contains three bedrooms, two bathrooms in addition to the living room and a kitchen Figs. 5 and has two walls facing the outside. The sun enters each apartment through five windows, but the shading elements are installed and tested only on three windows of each apartment, as the other two windows already have a horizontal overhang of $1.0 \mathrm{~m}$.

The standard building materials are listed in Table II. The glazing type is double glazing, clear glass, with $3 \mathrm{~mm}$ thickness of each pane, the air layer between the panes is $6 \mathrm{~mm}$ and no shading elements are attached. The total window/floor area is $85 \mathrm{~m}^{2}$; therefore, the window to wall ratio is $27 \%$, this allows a high level of direct sunlight within the units. Besides, a split unit system is used for mechanical heating and cooling, which is powered by electricity from the grid and consumes a huge amount of energy annually.

\section{A. Scenarios and Variables}

Since thermal comfort and reduction of energy consumption for cooling, heating, lighting, or other purposes depend heavily on the orientation of the building and its opening(Ashmawy and Azmy, 2018) and also the amount of solar radiation strongly depends on the orientation of the building. Therefore, two scenarios were determined for the simulation based on the change in the orientation of the

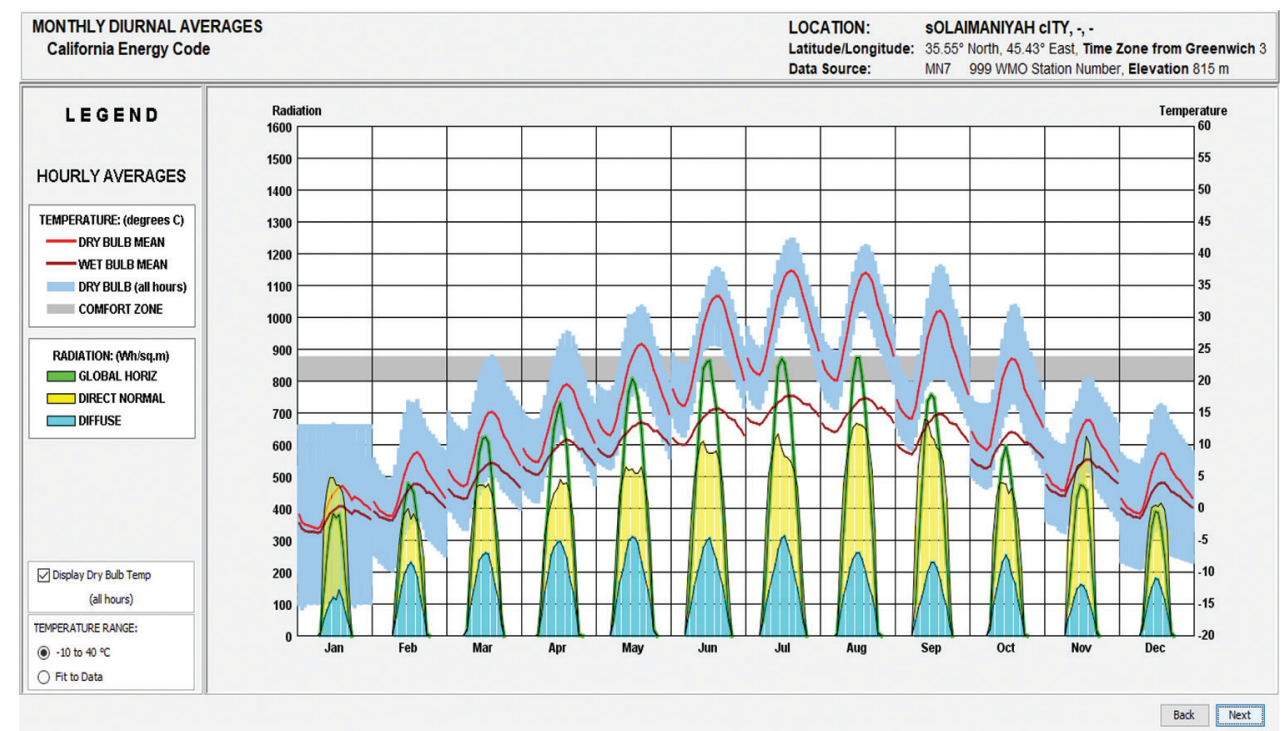

Fig. 2. Sulaimani monthly diurnal averages, based on the Sulaimani weather data file. Reproduced by Climate consultant were by electricity from the grid and consumes a huge amount of energy annually.

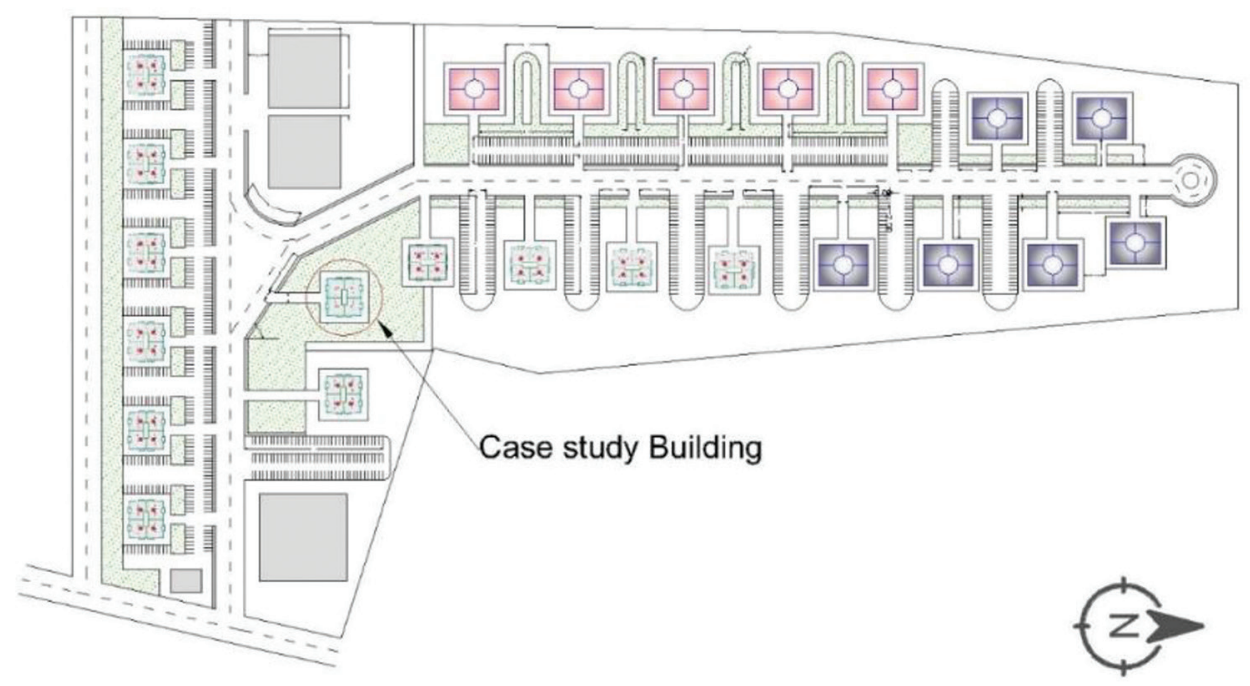

Fig. 3. Darwaza city site plan and the studied building located on it (Source: Author). 


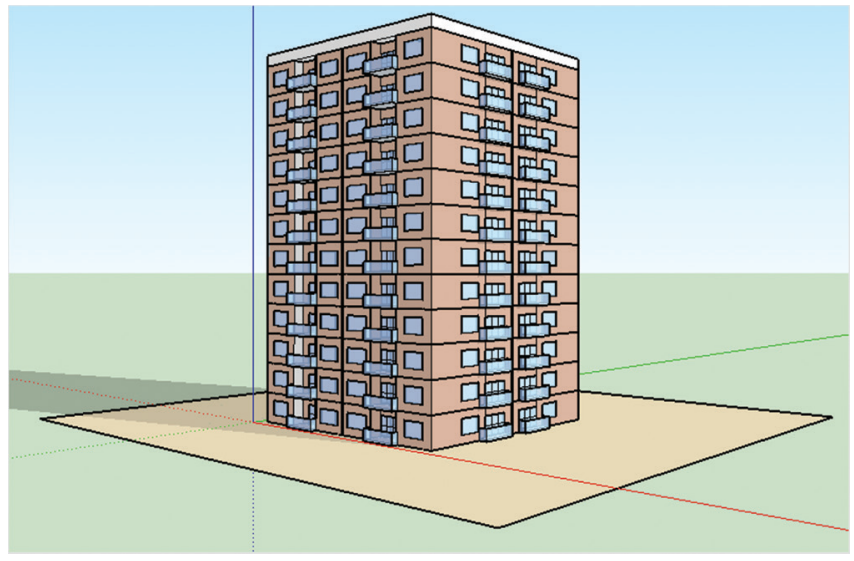

Fig. 4. Case study building model constructed in SketchUp (Source: Author). case building. Scenario A is oriented in all four directions (north, east, south, and west), which it is the real building orientation, and scenario $\mathrm{B}$ is rotated $45^{\circ}$ from the north, Figs. 6 and 7. Table I illustrates the setting of the two scenarios. However, the other variables in this study are the design and sizing of the shading elements and their effect on the annual cooling loads, which will be described in detail later.

\section{B. The Shading Models, Configurations, and Details}

The main objective in installing shading devices on a window is to prevent direct sunlight from entering the buildings and thus reduces overheating. According to the Sun shading table of the climate consultant software (Milne and

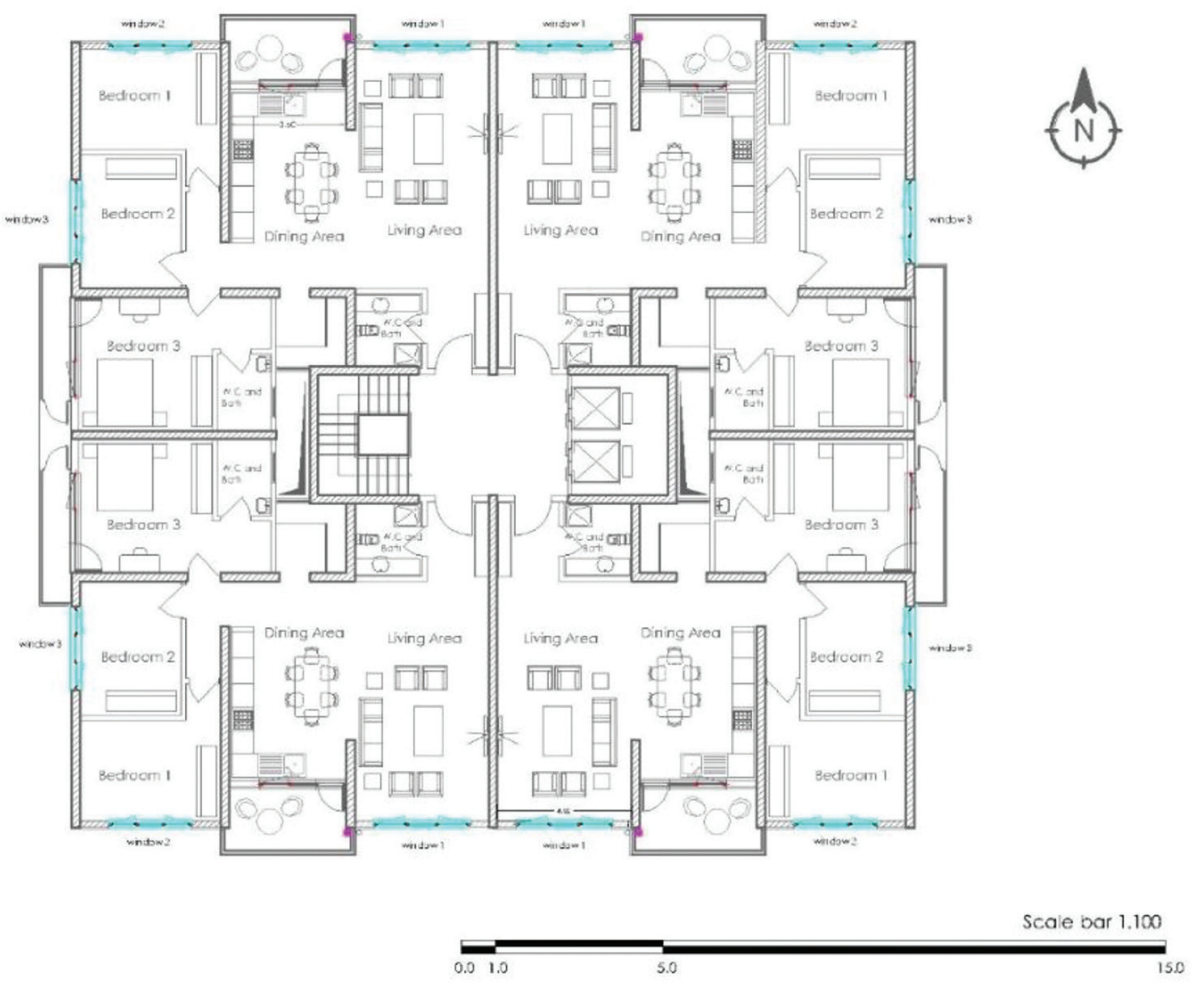

Fig. 5. Case study building typical floor layout (Source: Author).

TABLE I

THE ILLUSTRATIONS FOR THE SETTING OF THE TWO SIMULATION SCENARIOS AND THE ORIENTATION OF THE APARTMENTS IN THE PROTOTYPE BUILDING (SOURCE: AUTHOR)

\begin{tabular}{|c|c|c|c|c|c|c|c|c|}
\hline \multirow[t]{2}{*}{ Apartment } & \multicolumn{4}{|c|}{ Scenario A } & \multicolumn{4}{|c|}{ Scenario B } \\
\hline & $\begin{array}{l}\text { Scenario -A-apartment } \\
\text { code }\end{array}$ & $\begin{array}{l}\text { Scenario -A-apartment } \\
\text { orientation }\end{array}$ & $\begin{array}{l}\text { Window } \\
\text { code }\end{array}$ & $\begin{array}{l}\text { Window } \\
\text { orientation }\end{array}$ & $\begin{array}{l}\text { Scenario -B-apartment } \\
\text { code }\end{array}$ & $\begin{array}{l}\text { Scenario -B-apartment } \\
\text { orientation }\end{array}$ & $\begin{array}{l}\text { Window } \\
\text { code }\end{array}$ & $\begin{array}{l}\text { Window } \\
\text { orientation }\end{array}$ \\
\hline \multirow{2}{*}{1} & & & 1A-W2 & $\mathrm{N}$ & & & 1B-W2 & NW \\
\hline & & & $1 \mathrm{~A}-\mathrm{W} 3$ & $\mathrm{E}$ & & & 1B-W3 & $\mathrm{NE}$ \\
\hline 2 & $2 \mathrm{~A}$ & $\mathrm{~N}, \mathrm{~W}$ & 2A-W1 & $\mathrm{N}$ & $2 \mathrm{~B}$ & NW, SW & 2B-W1 & NW \\
\hline \multirow[t]{3}{*}{3} & $3 \mathrm{~A}$ & $\mathrm{~S}, \mathrm{E}$ & 3A-W1 & $\mathrm{S}$ & $3 B$ & NE, SE & 3B-W1 & $\mathrm{SE}$ \\
\hline & & & 3A-W2 & $\mathrm{S}$ & & & 3B-W2 & SE \\
\hline & & & $3 \mathrm{~A}-\mathrm{W} 3$ & $\mathrm{E}$ & & & $3 \mathrm{~B}-\mathrm{W} 3$ & $\mathrm{NE}$ \\
\hline \multirow[t]{3}{*}{4} & $4 \mathrm{~A}$ & $\mathrm{~S}, \mathrm{~W}$ & 4A-W1 & $\mathrm{S}$ & $4 \mathrm{~B}$ & SE, SW & 4B-W1 & SE \\
\hline & & & 4A-W2 & $\mathrm{S}$ & & & 4B-W2 & SE \\
\hline & & & $4 \mathrm{~A}-\mathrm{W} 3$ & W & & & 4B-W3 & SW \\
\hline
\end{tabular}


TABLE II

Real CASE BUilding CONSTRUCTION MATERIALs (SOURCE: Author)



Liggett, 2019), Sulaimani climate has $1217 \mathrm{~h}$ of sunshine in the summer-autumn season from June 21 to December 21, when the temperature is higher than $27^{\circ} \mathrm{C}$, which is perceived as unpleasant and requires shade, Fig. 8.

Therefore, a comparative analysis between horizontal and vertical shading elements (with different depth and number) was performed on the described building windows on all orientations in both scenarios to evaluate their impact on the annual cooling energy consumption. Furthermore, the proper depth, shape, and number of elements that would result in a higher reduction of cooling energy for Sulaimani climate were determined and tested with DesignBuilder. As the sixth floor is located in the middle of the building (12 floors + the ground floor), it was selected to study, assuming that the results are almost the same for all the apartments of the building.

According to the Sun shading table of the climate consultant software (Milne and Liggett, 2019), Sulaimani climate has $1217 \mathrm{~h}$ of sunshine in the summer-autumn season from June 21 to December 21

Table III shows the configuration of the shading elements tested in this study. The most suitable and reasonable shapes and widths are tested according to the altitude angle of the city of Sulaimani, which is about $80^{\circ}$ maximum in June and $30^{\circ}$ minimum in December (Milne and Liggett,

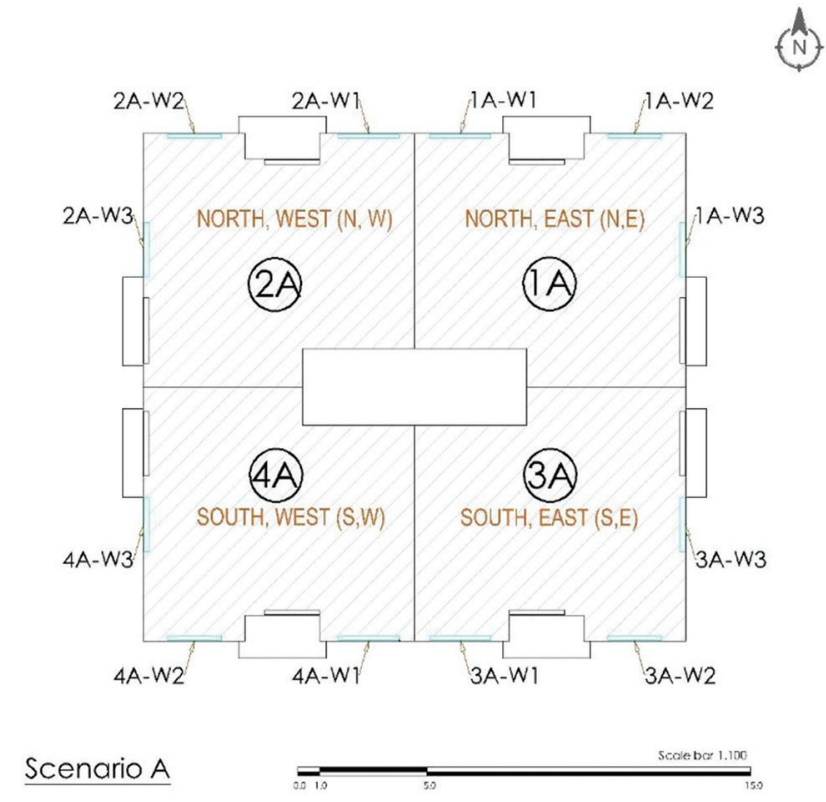

Fig. 6. Scenario (A) case study real orientations (North, East, South, and West) - Plan (Source: Author).

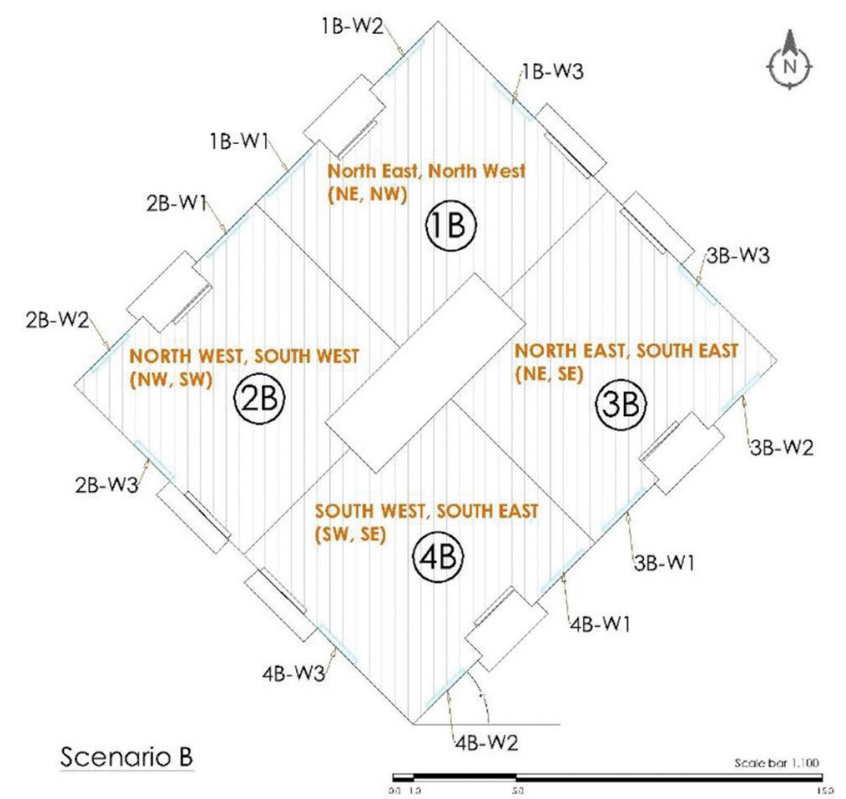

Fig. 7. Scenario (B) case study orientation rotated $45^{\circ}$ from the North Plan (Source: Author), when the temperature is higher than $27^{\circ} \mathrm{C}$, which is perceived as unpleasant and requires shade, Fig. 8.

2019). Therefore, the effect of single, double, and triple fixed horizontal shading devices on the cooling energy performance of each apartment will be tested. The length of the horizontal blinds was determined according to the width of the windows, which is $250 \mathrm{~cm}$. As with the vertical units, fixed shading devices are chosen and tested at three different depths along the length of the window, as shown in Table III and Fig. 9.

Depths greater than $60 \mathrm{~cm}$ are not considered, as this is not practical and negatively affects natural lighting and 


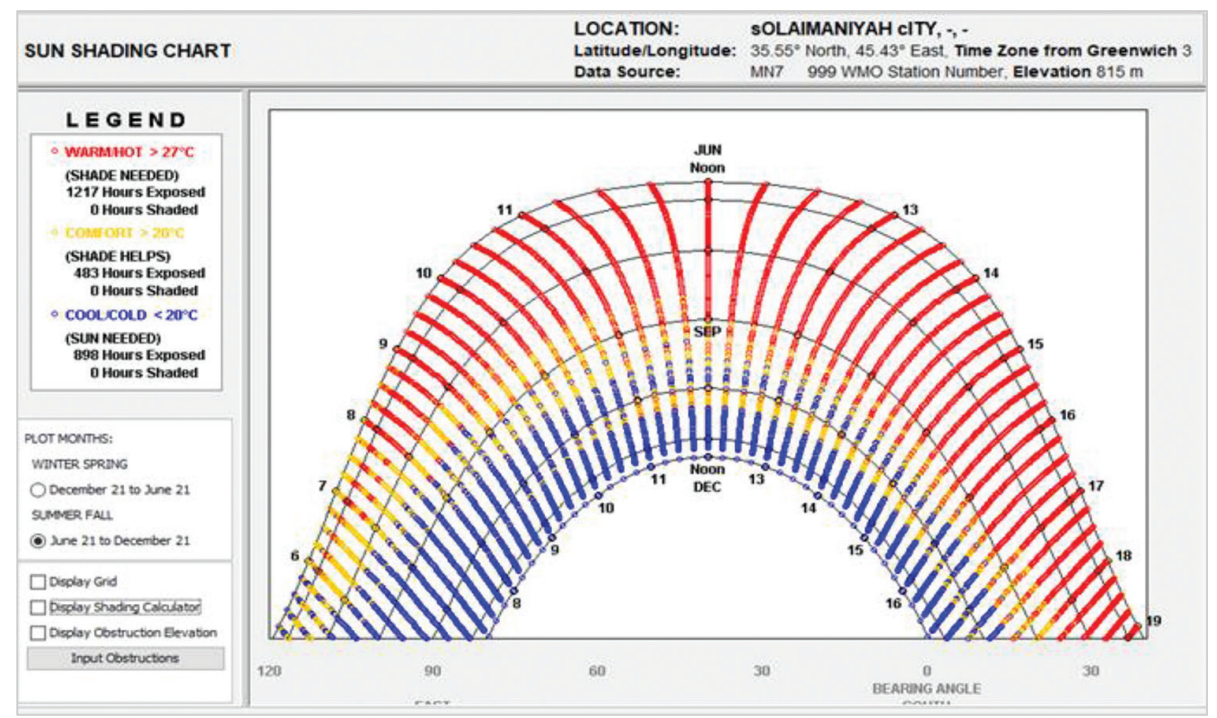

Fig. 8. Sun shading chart reproduced from climate consultant 6.0 software (Milne and Liggett, 2019).

TABLE III

SHADING ELEMENTS ARRANGEMENT AND NUMBER (SOURCE: AutHor)

\begin{tabular}{|c|c|c|c|c|}
\hline \multicolumn{3}{|c|}{ Horizontal shading elements } & \multicolumn{2}{|c|}{ Vertical shading elements } \\
\hline $\begin{array}{c}\text { Number of } \\
\text { louvers }\end{array}$ & Width $(\mathrm{cm})$ & & Number of fins & Width $(\mathrm{cm})$ \\
\hline \multirow{2}{*}{1} & 60 & & & 60 \\
\hline & \multicolumn{2}{|c|}{ Horizontal shading elements } & \multicolumn{2}{|c|}{ "Horizontal shading elements } \\
\hline $\begin{array}{c}\text { Number of } \\
\text { louvers }\end{array}$ & $\begin{array}{l}\text { Width } \\
(\mathrm{cm})\end{array}$ & & $\begin{array}{c}\text { Number of } \\
\text { louvers }\end{array}$ & $\begin{array}{l}\text { Width } \\
(\mathrm{cm})\end{array}$ \\
\hline \multirow[t]{2}{*}{2} & 20 & & 3 & 20 \\
\hline & 40 & & & 40 \\
\hline
\end{tabular}




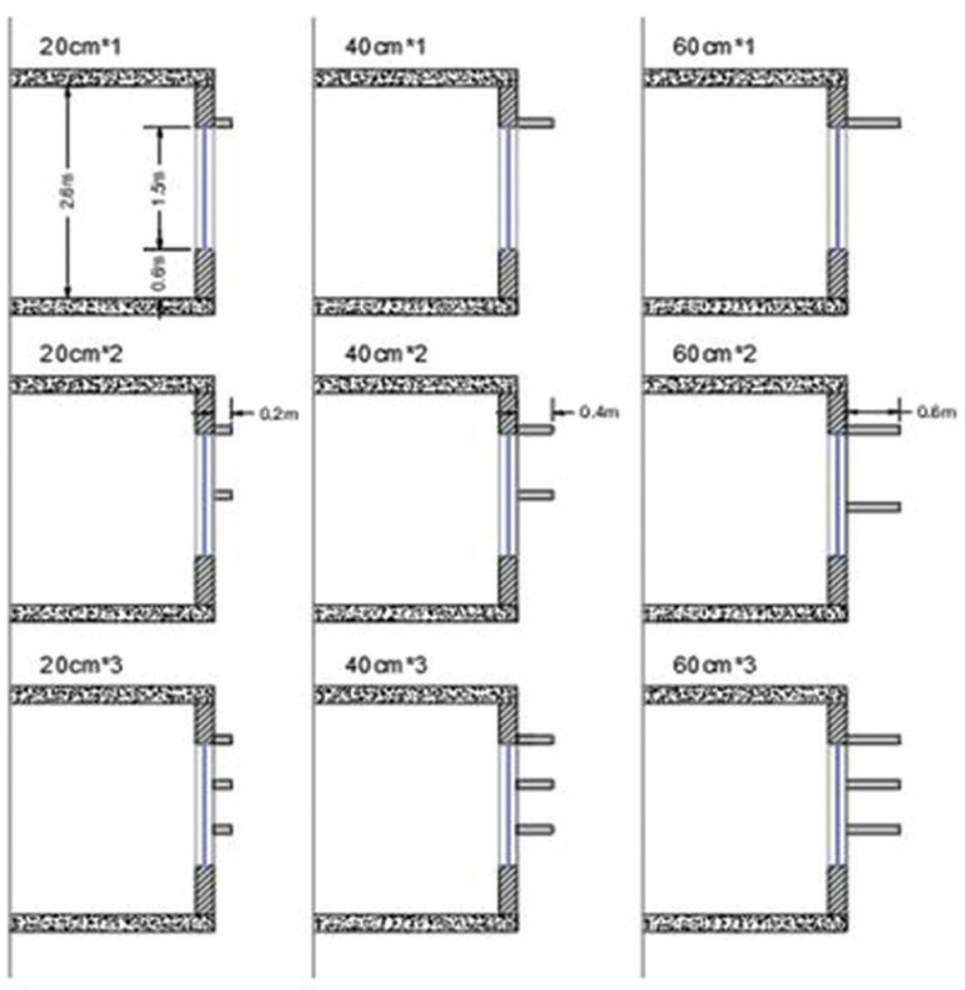

Sections to illustrate the horizontal
shading configurations
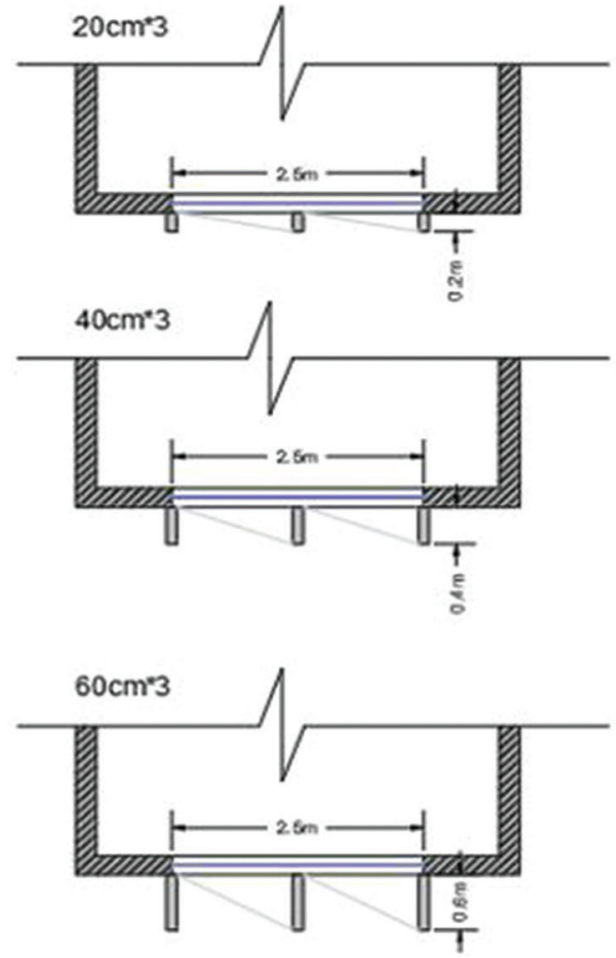

\section{Plans to illustrate the vertical shading configurations}

Fig. 9. Plans and sections of the shading elements arrangement and dimensions (Source: Author).

obstructs visibility according to previous studies. Besides, the thickness of all slats has been set at a fixed $10 \mathrm{~cm}$ and all are made of concrete.

\section{The Simulation}

The case study high-rise residential building has been modeled in the DesignBuilder software based on the actual building specifications and construction materials and entering the Sulaimani EnergyPlus weather data file into the software, the operating temperature was set for the operation of mechanical cooling with the split-unit system and natural ventilation was switched off, Table IV. The cooling period starts from April to the end of October. However, the annual cooling load consumption is also recorded from the simulation to evaluate the impact of the fixed shading devices on it. Therefore, a simulation of the annual energy consumption was performed for scenarios A and B, with 13 individual simulations for each scenario. The first simulation refers to the energy performance of each floor plan including four apartments without shading devices, nine simulations for the horizontal shading elements, and the last three simulations refer to the vertical shading elements Fig. 8. A total of 26 simulations were carried out for each floor plan to evaluate and to analyze the best shading device for each scenario and orientation.
TABLE IV

TEMPERATURE INDICATORS OF THE MECHANICAL SPLIT UNIT COOLING SYSTEM SET FOR THE CASE STUDY ( CIBSE, 2006)

\begin{tabular}{lcc}
\hline \hline Room & $\begin{array}{c}\text { Cooling air supply } \\
\text { temperature }{ }^{\circ} \mathrm{C}\end{array}$ & $\begin{array}{c}\text { Cooling set back } \\
\text { temperature }{ }^{\circ} \mathrm{C}\end{array}$ \\
\hline Living room & 21 & 25 \\
Kitchen & 19 & 22 \\
Bedrooms & 21 & 25 \\
Bathrooms & 22 & 25 \\
Circulation & 21 & 25 \\
Store & 21 & 25 \\
\hline \hline
\end{tabular}

\section{RESULTS AND DiscusSION}

The simulation analysis results show that the months April to October are considered hot months in which cooling systems are highly required. The results indicate that a change in orientation of the building and other variables such as the width and number of shading elements, influence the level of cooling loads inside the modeled residential building.

The total annual cooling load required for each floor is $29,494 \mathrm{~kW} / \mathrm{h}$ without installation of shading for scenario A, whereas for scenario B the total is $30,204 \mathrm{~kW} / \mathrm{h}$. August shows the highest energy demand for cooling for all alignments before and after the installation of shading devices. 


\section{A. Horizontal Louvers}

After simulating the model without shading devices, a single fixed horizontal louver was installed on the top of the windows. In general, the results showed that for both scenarios (A and B), a single fixed horizontal louver with a depth of $20 \mathrm{~cm}$ reduced the cooling loads by only $2 \%$ of the total annual cooling loads, Table V.

However, in some orientations, the extension of the louver width has improved the performance of the blades. Individual fixed louvers with a width of $40 \mathrm{~cm}$ and $60 \mathrm{~cm}$ do not show a significant reduction in cooling loads for apartments $1 \mathrm{~A}$, $1 \mathrm{~B}$ and $2 \mathrm{~A}, 2 \mathrm{~B}$, as shown in Table VI. Yet, the effect of the width expansion is noticeable with the $60 \mathrm{~cm}$ wide fixed individual louver and reaches about $5.0 \%$ for apartments 3 and 4 in both scenarios.

Nevertheless, the effect of adding another fixed louver to the $40 \mathrm{~cm}$ and $60 \mathrm{~cm}$ deep slats of the windows is more obvious and the reduction in energy consumption is almost twice as high as with the single fixed horizontal shading device. For a moment, the double fixed $60 \mathrm{~cm}$ louver led to a maximum $9.4 \%$ reduction of cooling loads in apartment $4 \mathrm{~B}$, whereas, the least reduction, however, is $3.4 \%$ for apartment 2A when using a $40 \mathrm{~cm}$ louver. Moreover, the role of changing the orientation of the building is evident.
The effect of using double fixed blades on the cooling load of the same flat with different orientation cannot be ignored. For example, the difference in cooling load reduction for apartments 2A oriented North West $(\mathrm{N}, \mathrm{W})$ and 2B oriented northwest-southwest (NW, SW) is around 2.5\%, as shown in Table VII.

Meanwhile, the $40 \mathrm{~cm}$ triple fixed blinds have an almost similar effect of the $60 \mathrm{~cm}$ triple fixed blinds on the reduction of the cooling loads for both scenarios $\mathrm{A}$ and $\mathrm{B}$. Therefore, the $40 \mathrm{~cm}$ triple fixed blinds are more efficient, as the results in Table VIII show. Compared with the study by (AbdelMonteleb, 2013) which is carried out for hot, and arid desert climate, the results are more dissimilar with increasing horizontal shading, the greater the overhang, the lower the ambient temperature.

\section{B. Vertical Fins}

After analyzing the data, as shown in Table IX, it can be concluded that the maximum reduction of cooling loads can reach almost 5\% after installing triple fixed vertical shading elements. However, the $20 \mathrm{~cm}$ vertical fins have an insignificant influence on the cooling loads. Except for apartments 3B (NE, SE) and 4B (SW, SE), which reaches about $3.0 \%$.

TABLE V

EFFECT OF SINGLE FIXED HORIZONTAL SHADING DEVICES (20 CM WIDTH) ON BOTH SCENARIOS A AND B (SOURCE: AUTHOR)

\begin{tabular}{|c|c|c|c|c|c|c|c|c|c|}
\hline \multirow[t]{3}{*}{$\overline{\text { Apartment }}$} & \multicolumn{4}{|c|}{ Scenario A } & \multirow[t]{3}{*}{ Apartment } & \multicolumn{4}{|c|}{ Scenario B } \\
\hline & \multicolumn{2}{|c|}{ Annual cooling load } & \multirow{2}{*}{$\begin{array}{c}\text { Reduction } \\
\mathrm{kW}\end{array}$} & \multirow{2}{*}{$\begin{array}{l}\text { Reduction } \\
\text { percentage }\end{array}$} & & \multicolumn{2}{|c|}{ Annual cooling load } & \multirow[t]{2}{*}{ Reduction $\mathrm{kW}$} & \multirow{2}{*}{$\begin{array}{l}\text { Reduction } \\
\text { percentage }\end{array}$} \\
\hline & $\begin{array}{c}\text { Without } \\
\text { shade }(\mathrm{kW})\end{array}$ & $\begin{array}{c}\text { With } \\
\text { shade }(\mathrm{kW})\end{array}$ & & & & $\begin{array}{c}\text { Without } \\
\text { shade }(\mathrm{kW})\end{array}$ & $\begin{array}{c}\text { With } \\
\text { shade }(\mathrm{kW})\end{array}$ & & \\
\hline$\overline{N, E}$ & 7327 & 7265 & 62 & $0.8 \%$ & NE, NW & 7391 & 7324 & 67 & $0.9 \%$ \\
\hline $\mathrm{N}, \mathrm{W}$ & 7076 & 7037 & 39 & $0.6 \%$ & NW, SW & 7615 & 7491 & 124 & $1.6 \%$ \\
\hline S, E & 7671 & 7514 & 157 & $2 \%$ & NE, SE & 7532 & 7447 & 85 & $1.1 \%$ \\
\hline
\end{tabular}

TABLE VI

EFFECTS OF SINGLE FIXED HORIZONTAL LOUVERS ON BOTH SCENARIOS A AND B (WIDTH OF 40 CM AND 60 CM) ON THE ANNUAL COOLING LOADS (SOURCE: AUTHOR)

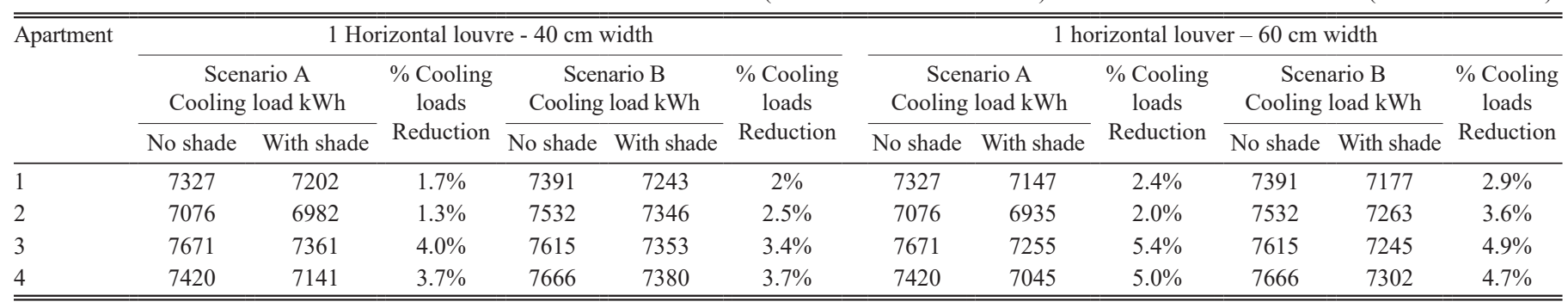

TABLE VII

EFFECTS OF DOUBLE FIXED HORIZONTAL LOUVERS, SCENARIOS A AND B (WIDTH OF 40 CM AND 60 CM) ON THE ANNUAL COOLING LOADS (SOURCE: AUTHOR)

\begin{tabular}{|c|c|c|c|c|c|c|c|c|c|c|c|c|}
\hline \multirow[t]{3}{*}{ Apartment } & \multicolumn{6}{|c|}{2 2 Horizontal louvers $-40 \mathrm{~cm}$ width } & \multicolumn{6}{|c|}{2 2 Horizontal louvers $-60 \mathrm{~cm}$ width } \\
\hline & \multicolumn{2}{|c|}{$\begin{array}{c}\text { Scenario A } \\
\text { Cooling load kWh }\end{array}$} & \multirow{2}{*}{$\begin{array}{l}\text { \% Cooling } \\
\text { loads } \\
\text { Reduction }\end{array}$} & \multicolumn{2}{|c|}{$\begin{array}{c}\text { Scenario B } \\
\text { Cooling load kWh }\end{array}$} & \multirow{2}{*}{$\begin{array}{c}\% \text { Cooling } \\
\text { loads } \\
\text { Reduction }\end{array}$} & \multicolumn{2}{|c|}{$\begin{array}{c}\text { Scenario A } \\
\text { Cooling load kWh }\end{array}$} & \multirow{2}{*}{$\begin{array}{c}\text { \% Cooling } \\
\text { loads } \\
\text { Reduction }\end{array}$} & \multicolumn{2}{|c|}{$\begin{array}{c}\text { Scenario B } \\
\text { Cooling load kWh }\end{array}$} & \multirow{2}{*}{$\begin{array}{c}\text { \% Cooling } \\
\text { loads } \\
\text { Reduction }\end{array}$} \\
\hline & No shade & With shade & & No shade & With shade & & No shade & With shade & & No shade & With shade & \\
\hline 1 & 7327 & 7026 & $4.0 \%$ & 7391 & 7025 & $5.0 \%$ & 7327 & 6986 & $4.6 \%$ & 7391 & 6977 & $5.6 \%$ \\
\hline 2 & 7076 & 6832 & $3.4 \%$ & 7532 & 7098 & $5.8 \%$ & 7076 & 6798 & $4 \%$ & 7532 & 7035 & $6.6 \%$ \\
\hline 3 & 7671 & 7080 & $7.7 \%$ & 7615 & 7049 & $7.4 \%$ & 7671 & 7017 & $8.5 \%$ & 7615 & 6963 & $8.5 \%$ \\
\hline
\end{tabular}


TABLE VIII

EFFECTS OF TRIPLE FIXED HORIZONTAL LOUVERS ON SCENARIOS A AND B (WIDTH OF 20 CM, 40 CM AND 60 CM) ON THE ANNUAL COOLING LOADS (SOURCE: AUTHOR)

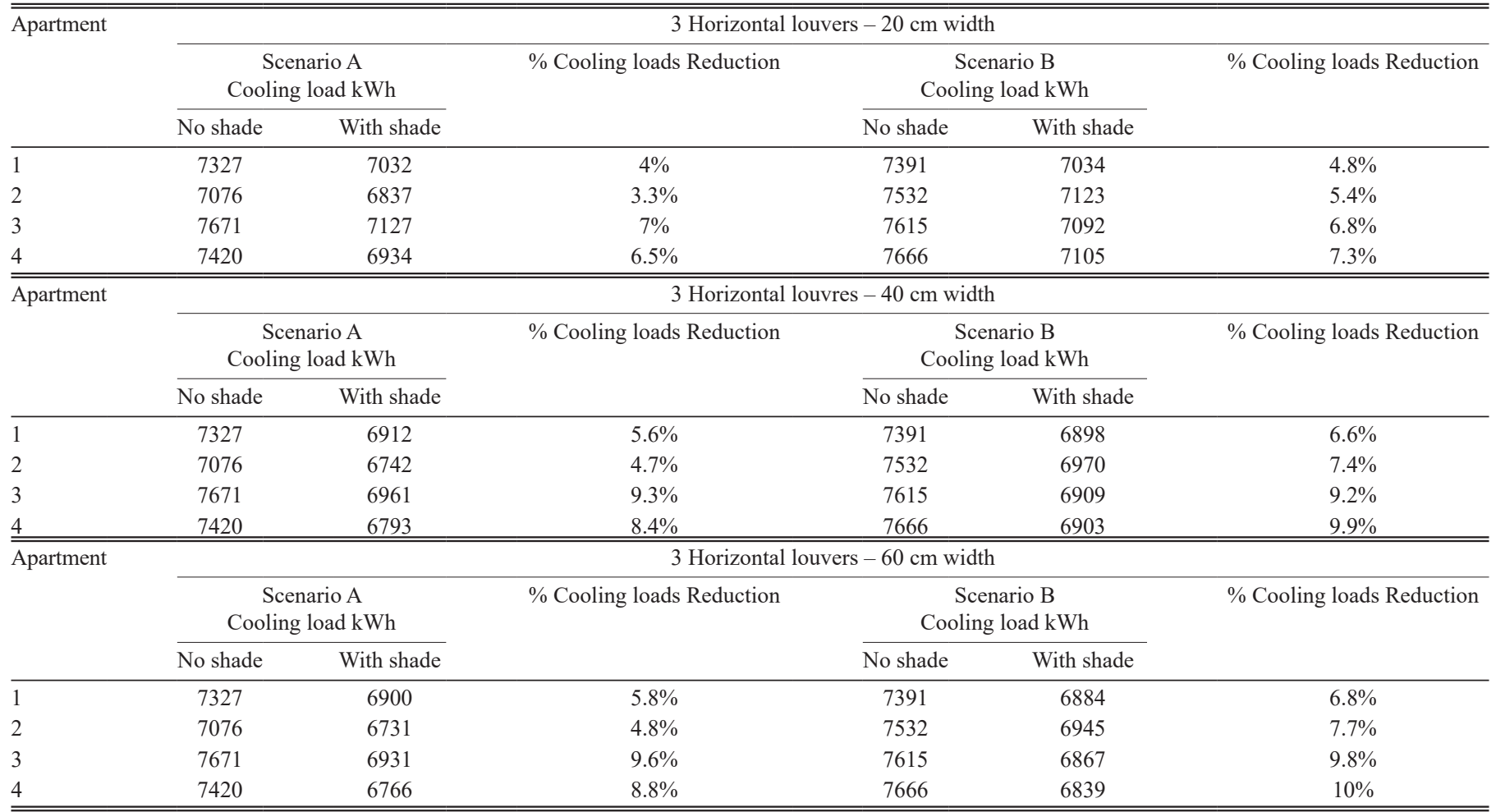

TABLE IX

EFFECTS OF TRIPLE FIXED VERTICAL SHADING ELEMENTS ON SCENARIOS A AND B (WIDTH OF 20 CM, 40 CM AND 60 CM) ON THE ANNUAL COOLING LOADS (SOURCE: AUTHOR)

\begin{tabular}{|c|c|c|c|c|c|c|}
\hline \multirow[t]{3}{*}{ Apartment } & \multicolumn{6}{|c|}{$\begin{array}{l}\text { Vertical Shading Elements }-20 \mathrm{~cm} \text { width } \\
\end{array}$} \\
\hline & \multicolumn{2}{|c|}{$\begin{array}{c}\text { Scenario A } \\
\text { Cooling load kWh }\end{array}$} & \multirow[t]{2}{*}{$\%$ Cooling loads reduction } & \multicolumn{2}{|c|}{$\begin{array}{c}\text { Scenario B } \\
\text { Cooling load kWh }\end{array}$} & \multirow[t]{2}{*}{$\%$ Cooling loads reduction } \\
\hline & No shade & With shade & & No shade & With shade & \\
\hline 1 & 7327 & 7168 & $2.2 \%$ & 7391 & 7189 & $2.7 \%$ \\
\hline 2 & 7076 & 6940 & $1.9 \%$ & 7532 & 7321 & $2.8 \%$ \\
\hline 3 & 7671 & 7456 & $2.8 \%$ & 7615 & 7371 & $3.2 \%$ \\
\hline \multirow{2}{*}{ Apartment } & \multicolumn{2}{|c|}{$\begin{array}{c}\text { Scenario A } \\
\text { Cooling load kWh }\end{array}$} & \multirow[t]{2}{*}{$\%$ Cooling loads reduction } & \multicolumn{2}{|c|}{$\begin{array}{c}\text { Scenario B } \\
\text { Cooling load kWh }\end{array}$} & $\%$ Cooling loads reduction \\
\hline & No shade & With shade & & No shade & With shade & \\
\hline 1 & 7327 & 7103 & $3 \%$ & 7391 & 7080 & $4.2 \%$ \\
\hline 2 & 7076 & 6878 & $2.8 \%$ & 7532 & 7207 & $4.3 \%$ \\
\hline \multirow[t]{2}{*}{$\overline{\text { Apartment }}$} & \multicolumn{6}{|c|}{3 Vertical Shading Elements $-60 \mathrm{~cm}$ width } \\
\hline & No shade & With shade & $\%$ Cooling loads reduction & No shade & With shade & \\
\hline 1 & 7327 & 7119 & $2.8 \%$ & 7391 & 7065 & $4.4 \%$ \\
\hline 2 & 7076 & 6886 & $2.7 \%$ & 7532 & 7205 & $4.3 \%$ \\
\hline 3 & 7671 & 7409 & $3.4 \%$ & 7615 & 7251 & $4.7 \%$ \\
\hline 4 & 7420 & 7175 & $3.3 \%$ & 7666 & 7319 & $4.5 \%$ \\
\hline
\end{tabular}

For the triple fixed $40 \mathrm{~cm}$ slats, as far as the scenarios are concerned, the percentages of reducing the cooling loads are higher in scenario $\mathrm{B}$ because of alignment. The highest reduction is $4.8 \%$ and can be seen in apartment
$3 \mathrm{~B}$, orientation NE, SE. Yet, even if the depth of the slats is increased from $40 \mathrm{~cm}$ to $60 \mathrm{~cm}$ for both scenarios, still the $40 \mathrm{~cm}$ fixed slats are more effective in reducing solar radiation than the slats with $60 \mathrm{~cm}$ depth. 
TABLE X

THE EFFeCt OF TRIPLE FIXED VERTICAL AND HORIZONTAL SHADING DEVICES (40 CM WIDTH) ON SCENARio A (SourCE: Author)

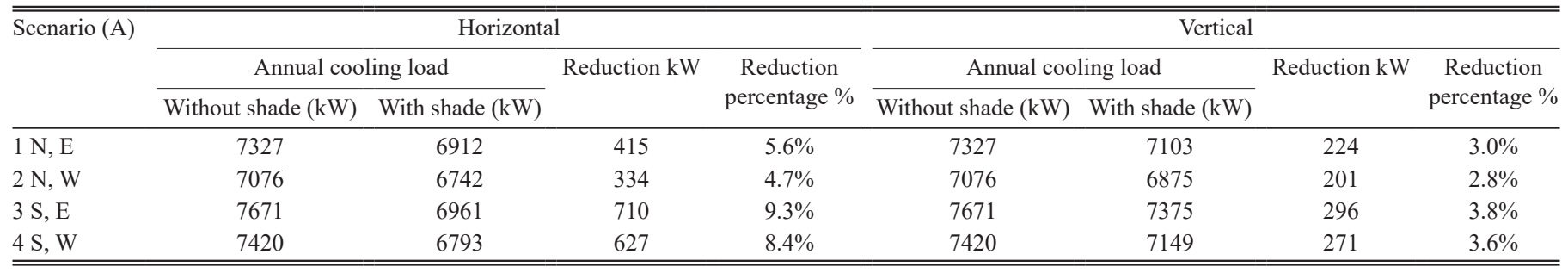

TABLE XI

THE EFFECT OF TRIPLE FIXED VERTICAL AND HORIZONTAL SHADING DEVICES (40 CM WIDTH) ON SCENARIO B (SOURCE: AUTHOR)

\begin{tabular}{|c|c|c|c|c|c|c|c|c|}
\hline \multirow[t]{3}{*}{ Scenario (B) } & \multicolumn{4}{|c|}{ Horizontal } & \multicolumn{4}{|c|}{ Vertical } \\
\hline & \multicolumn{2}{|c|}{ Annual cooling load } & \multirow[t]{2}{*}{ Reduction kW } & \multirow{2}{*}{$\begin{array}{c}\text { Reduction } \\
\text { percentage } \%\end{array}$} & \multicolumn{2}{|c|}{ Annual cooling load } & \multirow[t]{2}{*}{ Reduction $\mathrm{kW}$} & \multirow{2}{*}{$\begin{array}{c}\text { Reduction } \\
\text { percentage } \%\end{array}$} \\
\hline & Without shade $(\mathrm{kW})$ & With shade (kW) & & & Without shade $(\mathrm{kW})$ & With shade $(\mathrm{kW})$ & & \\
\hline $2 \mathrm{NW}, \mathrm{SW}$ & 7532 & 6970 & 562 & $7.4 \%$ & 7532 & 7207 & 325 & $4.3 \%$ \\
\hline $3 \mathrm{NE}, \mathrm{SE}$ & 7615 & 6909 & 706 & $9.2 \%$ & 7615 & 7245 & 370 & $4.8 \%$ \\
\hline $4 \mathrm{SE}, \mathrm{SW}$ & 7666 & 6903 & 763 & $9.9 \%$ & 7666 & 7306 & 360 & $4.7 \%$ \\
\hline
\end{tabular}

There is a similarity between the above-mentioned result and the results of a research on the influence of vertical shading devices on thermal performance for hot, arid climate (Abd El-Monteleb and Ahmed, 2012) only for the north facade. Because the results showed that the lower the ambient temperature for other facades, the greater the projection, whereas an increase in the length of more than 38 $\mathrm{cm}$ is insignificant for the north facade.

\section{Comparison between the Horizontal and Vertical $40 \mathrm{~cm}$}

\section{Wide Louvers}

It is shown from Table $\mathrm{X}$ and Table $\mathrm{XI}$ that the fixed horizontal slats work better than the fixed vertical slats in both scenarios. In Scenario A, the vertical slats, the maximum percentage of annual cooling loads reduction is of the apartment $3 \mathrm{~A}$, by $3.8 \%$. Whilst, the horizontal louvers performed better and the least reduction was $4.7 \%$ in apartment $2 \mathrm{~A}$ and went up to $9.3 \%$ in apartment $3 \mathrm{~A}$. As of Scenario B, the positive effect of the fixed horizontal slats is noticeable for all apartments; the decrease is ranged between $6.6 \%$ and $9.9 \%$. However, the highest effect of the fixed vertical shading elements can be observed in apartment $3 \mathrm{~B}$, where the reduction is only $4.8 \%$.

\section{CONCLUSIONS}

This research looked at the impact of modifying fixed horizontal and vertical concrete shading components through different orientations in Sulaimani weather conditions. To study aimed their effect on cooling energy consumption of a 13-storey residential building in the city. As far as the results are concerned, fixed shading devices can be used as an architectural element and as a climate-responsive strategy in the design of buildings in Sulaimani. Noticeably, a single horizontal louver with a depth of $20 \mathrm{~cm}$ installed on the top of any window, with any of the eight main orientations of a compass, is considered inefficient. Its effect can be almost neglected, as leads to a maximum reduction of the annual cooling loads of an apartment by only $2 \%$. Moreover, triple vertical shadings with a depth of $20 \mathrm{~cm}$, installed in the middle and on both sides of each window with any of the tested orientation, are considered inefficient too. As in both Scenarios A and B, they only affect the energy consumption for cooling the apartments by a maximum of only $3.2 \%$.

Conversely, the most effective fixed shading element is a triple horizontal with $60 \mathrm{~cm}$ width, for all the selected orientations of both scenarios. Its effectiveness results in a $7 \%$ reduction in the energy required for cooling the four apartments on one floor in scenario $\mathrm{A}$, and $9 \%$ in scenario B. Besides, the analyzed data illustrate that a $60 \mathrm{~cm}$ double horizontal shading device has almost the same effect as a $40 \mathrm{~cm}$ triple horizontal ones. As of the $40 \mathrm{~cm}$ and $60 \mathrm{~cm}$ triple vertical slats, the reductions in annual cooling demands are very close for both widths. In Scenario A; lead to a reduction of the cooling load in all apartments by almost 2.7$3.8 \%$. In Scenario B, however, the reduction of the cooling load is in the range of $4.2-4.8 \%$. In fact, the $40 \mathrm{~cm}$ deep fins are more efficient and are considered more effective.

Eventually, the triple $60 \mathrm{~cm}$ horizontal shading device has twice the effect on the cooling load of all apartments in Scenarios A and B than a triple-fixed $60 \mathrm{~cm}$ vertical shading device, except for apartments $3 \mathrm{~A}$ and $4 \mathrm{~A}$, where the fixed horizontal component has a triple effect.

In conclusion, these effective louvers according to the results are recommended to be used in high-rise residential buildings for hot climates from the early stages of design as a passive design strategy to contribute in lessening energy demand in high-rise residential buildings in particular and the residential sector in general.

\section{REFERENCES}

Abd El-Monteleb, A. and Ahmed, M.A., 2012. Using simulation for studying the influence of vertical shading devices on the thermal performance of residential 
buildings (Case study: New Assiut City). Ain Shams Engineering Journal, 3(2), pp.163-174.

Idchabani, R., El Ganaoui, M. and Sick, F., 2017. Analysis of exterior shading by overhangs and fins in hot climate. Energy Procedia, 139, pp.379-384.

AbdelMonteleb, A., 2013. Using simulation for studying the influence of horizontal shading device protrusion on the thermal performance of spaces in residential buildings. Alexandria Engineering Journal, 52(4), pp.787-796.

Ali, M.M. and Al-Kodmany, K., 2012. Tall Buildings and Urban Habitat of the $21^{\text {st }}$ Century: A Global Perspective. Buildings, 2(4), pp.384-423.

Alzoubi, H.H. and Al-Zoubi, A., 2010. Assessment of building façade performance in terms of daylighting and the associated energy consumption in architectural spaces: Vertical and horizontal shading devices for southern exposure facades. Energy Conversion and Management, 8(51), pp.1592-1599.

Arsalan, G. and Sev, A., 2014. Significant Issues in and Around High-Rise Residential Environments. Mimar Sinan Fine Arts University, Istanbul.

Ashmawy, R.E. and Azmy, N.Y., 2018. Buildings orientation and its impact on the energy consumption. The Academic Research Community Publication, 2(3), pp.35-49.

Athienitis, A. and Haghighat, F., 1992. A Study of the Effect of Solar Radiation on the indoor Environment. Amer Society of Heating, Anaheim, CA, pp.257-261.

CIBSE, 2006. CIBSE Guide A:Environmental Design. The Chartered Institution of Building Services Engineers, London, Norwich.

Date and Time Info., 2020. Date and Time. Available from: https://www. dateandtime.info/citycoordinates.php?id=98463. [Last accessed on 2020 Oct 16].

Datta, G., 2001. Effect of fixed horizontal louver shading devices on thermal perfomance of building by TRNSYS simulation. Renewable Energy, 23(3-4), pp.497-507.

DesignBuilder., 2018. Designbuilder Software ltd.v.5.5.2.3. Available from: https://www.designbuilder.co.uk. [Last accessed on 2018 Dec 01].

Kim, J.T. and Kim, G., 2010. Advanced external shading device to maximize visual and view performance. Indoor and Built Environment, 19(1), pp.65-72.

Kottek, M., Grieser, J., Beck, C., Rudolf, B. And Rubel, F., 2006. World Map of Köppen-Geiger Climate Classification. Meteorologische Zeitschrift, 15(3), pp.259-263.

Milne, N. and Liggett, R., 2019. Climate Consultant v.6 Build 15. Available from: http://www.energy-design-tools.aud.ucla.edu. [Last accessed on 2020 Oct 01].

Morad, D.H. and Ismail, S.K., 2017. A comparative study between the climate response strategies and thermal comfort of a traditional and contemporary houses in KRG: Erbil. Kurdistan Journal of Applied Research, 2(3), pp.1-11.

Neufert, E., Neufert, P. and Baiche, B., 2000. Neufert Architects' Data. $3^{\text {rd }}$ ed. Blackwell Publishing, Oxford.

Shaeri, J., Habibi, A., Yaghoubi, M. and Chokhachian, A., 2019. The optimum window-to-wall ratio in office buildings for hot-humid, hot-dry, and cold climates in Iran. Environments, 6, pp.5-16.

Shahdan, M., Ahmad, S. and Hussin, M.A., 2018. External Shading Devices for Energy Efficient Building. Vol. 117. IOP Conference Series: Earth and Environmental Science.

Tariq, S.H. and Jinia, M.A., 2012. Effect of fixed horizontal shading devices in south facing residential buildings at Dhaka, Bangladesh. Asian Journal of Applied Science and Engineering, 1(2), pp.9-19. 